\title{
The Impact of Ageing on Population Structure and Development Process of Different Levels of Bangladesh
}

\author{
Imtiaz Ahmed ${ }^{1} *$ \\ ${ }^{1}$ Department of Population Sciences, University of Dhaka, Bangladesh \\ *Correspondence: imtiazdmc@gmail.com
}

\begin{abstract}
Bangladesh is a small South-Asian country at the threshold of an amazing opportunity. Due to relatively young age of the population, there is tremendous possibility of economic development. However, this euphoria of demographic dividend often masks the fact that there is a time limit on this opportunity and as this population gets older, we will have a completely different age structure by 2050 with more people on the other side of 65 . That will create a substantial burden on our support structure and additional budget will be needed to cater to the demands of the elderly. But if we can play our cards right, then it is possible to manage that while sustaining the development curve. But we have to act now; otherwise it will be too late.
\end{abstract}

Keywords: Demographic dividend, Dependency ratio, Population pyramid, and National ageing policy

\section{BACKGROUND:}

Squeezed in a small area of $147,570 \mathrm{~km}^{2}(56,977$ square miles), Bangladesh housed a huge population of approximately 163 million (World Population Review, 2019). This means a very densely populated country, about 1115 people spread over a single square kilometer, or 2,889 people per square mile, making it the 10th in the world in terms of population density (World Population Review, 2019).

Currently Bangladesh has a triangular age structure reflecting a large young population at the base (Mabud, 2008). 40\% of the total population are in the $<15$ age group and a meager $6 \%$ constitute $60+$ population (Mabud, 2008). There is a vigorous debate about how to leverage this young age structure as a demographic bonus, reaping the benefits to 'demographic dividend' (Uddin \& Karim, 2016). However, euphoria about this phenomenon is diverting attention from a very important issue, a gradually increasing proportion of older people. As our total fertility rate (TFR) is declining, and crude UniversePG I www.universepg.com birth rate $(\mathrm{CBR})$ and crude death rates are approaching to equality, the proportion of young people will eventually decline. In addition, life expectancy is on the rise. According to the Bangladesh Bureau of Statistics 2009 report, life expectancy at birth in 2008 was 67 years, (66 for males and 68 for females). By 2017 it has increased to 72 years at birth, (70 for males and 74 for females) according to World Bank Data (2019). What this means is that the population trend Bangladesh is currently experiencing will reverse with a larger chunk of population becoming elderly while the base of young people will shrink.

Population projections based on achieving TFR 2.1 by year 2015, 2018 and 2021 all conclude that Bangladesh population will eventually stabilize between 220-230 million around 2051, and even though the absolute number of working age population may continue to rise up to that point the elderly group will show an astounding increase of more than $10 \%$ from the present level (Rahman et al., 2019; Mabud, 2008). 
This problem is not of us alone; one of the legacies of twentieth century has undoubtedly been the shift towards global population ageing (Sultana, 2011). In Less Developed Countries, or LDCs, on an average the OADR or old-age dependency ratio has been calculated as 0.2 , it is expected to rise to 0.4 by 2100 , similar rise will also occur in MDCs (Lee, 2011). World Bank figures (2019) has put OADR in Bangladesh around 7.6, which shows that there are about 08 elderly person per 100 working people to take care of.

This is on a slow but upward spiral and will have a tremendous impact on our population structure and socio economic condition in future. So ageing of the population is an emerging problem for Bangladesh and its consequences are far reaching (Rahman et al, 2007). Although on paper elderly people in Bangladesh consists of only a fraction of the total population compared to other South Asian countries, absolute figures are large due to sheer population size (Kabir, 1999). It is undeniable that dealing with this increasing elderly group poses a huge challenge for our government (Islam, 2011).

Bangladesh has an opportunity now to make maximum use of demographic dividend and prepare for the change in population structure in future. If that can be done the future is secure (Sharif et al., 2019). Otherwise, the shift in age structure will consume the socio-economic fabric. The burden on the working age will become too great to bear, state resources will diminish rapidly and all the gains made in the development process will vanish.

\section{Ageing trend and current situation in Bangladesh}

The median age of our population is 27.5 years in 2015 , but it is projected to increase gradually and by 2050 the median age will reach 40 years (Statista.com). This mean almost half the people of Bangladesh will be over 40 years of age and which will continue to rise (Habib et al., 2019). Because this shift appears to be happening within a relatively short time span, Bangladesh will have less time to deal with it. Fertility is the main factor influencing age structure of a population. When it becomes low, mortality comes into play (Kabir, 1998). Life expectancy also has an important role.

In Bangladesh, elderly people are rising both in absolute number and proportions for over a century, but only recently this trend has been identified:
Table 1: Population Ageing Trend in Bangladesh.

\begin{tabular}{|l|l|l|l|}
\hline Year & $\begin{array}{c}\text { Number of } \\
\text { 60 years and } \\
\text { above (in } \\
\text { millions) }\end{array}$ & $\begin{array}{c}\text { Percentage } \\
\text { of total } \\
\text { population }\end{array}$ & $\begin{array}{c}\text { Life } \\
\text { Expectancy } \\
\text { (years) }\end{array}$ \\
\hline 1974 & 4.0 & 5.7 & 46.2 \\
\hline 1981 & 4.9 & 5.6 & 54.8 \\
\hline 1991 & 6.0 & 5.4 & 56.1 \\
\hline 2001 & 7.9 & 6.1 & 64.9 \\
\hline 2007 & 9.41 & 6.6 & 66.8 \\
\hline 2010 & 10.9 & 7.0 & 68.6 \\
\hline
\end{tabular}

Sources:

BBS, 2003, 2008 Report on Sample Vital Registration System

BBS, 2008, Statistical Pocket Book of Bangladesh BBS, 2007, Population Census 2001, National Series, Volume-1, Analytical Report, P32-33, 6

U.S. Census Bureau, International Data Base

\section{Future projections}

In Bangladesh the median age of the population is expected to increase by 15 years by the year 2050, the ageing index is also predicted to be 5.7 times higher by then. Our sexagenarian population is projected to constitute 8.0 percent, 11.9 percent and 17 percent of total population by 2020, 2035 and 2050 respectively (Rahman, 2009).

While life expectancy was only 46 years at birth in 1974, it increased to 65.3 years in 2000 and then about 73 years in 2016, a gain of almost 7.7 years within 16 years (WHO, 2018). Our population pyramid is still triangular, showing large base of young people and a narrow top of older generation. However, the shape of age sex pyramid will change gradually and by 2050 it will become almost rectangular. This progressive change in shape is depicted below.

\section{Elderly support structure in Bangladesh}

In the social structure of Bangladesh family is the main support for the aged people. In the developed country there is an institutionalized system for elderly support but the traditional joint family structure has made it superfluous in Bangladesh until now. In low income countries, where social welfare programs for elderly are almost nonexistent or rudimentary, there is a high demand of support from family members, and 
kin availability and residential arrangement of elders are important factors for their well-being (UNFPA, 2009). There is a provision of mutual support between aged people and family members, as family support to elderly people are strong in Bangladesh which is influenced by socio cultural dynamics of our country (Kabir et al., 2002).

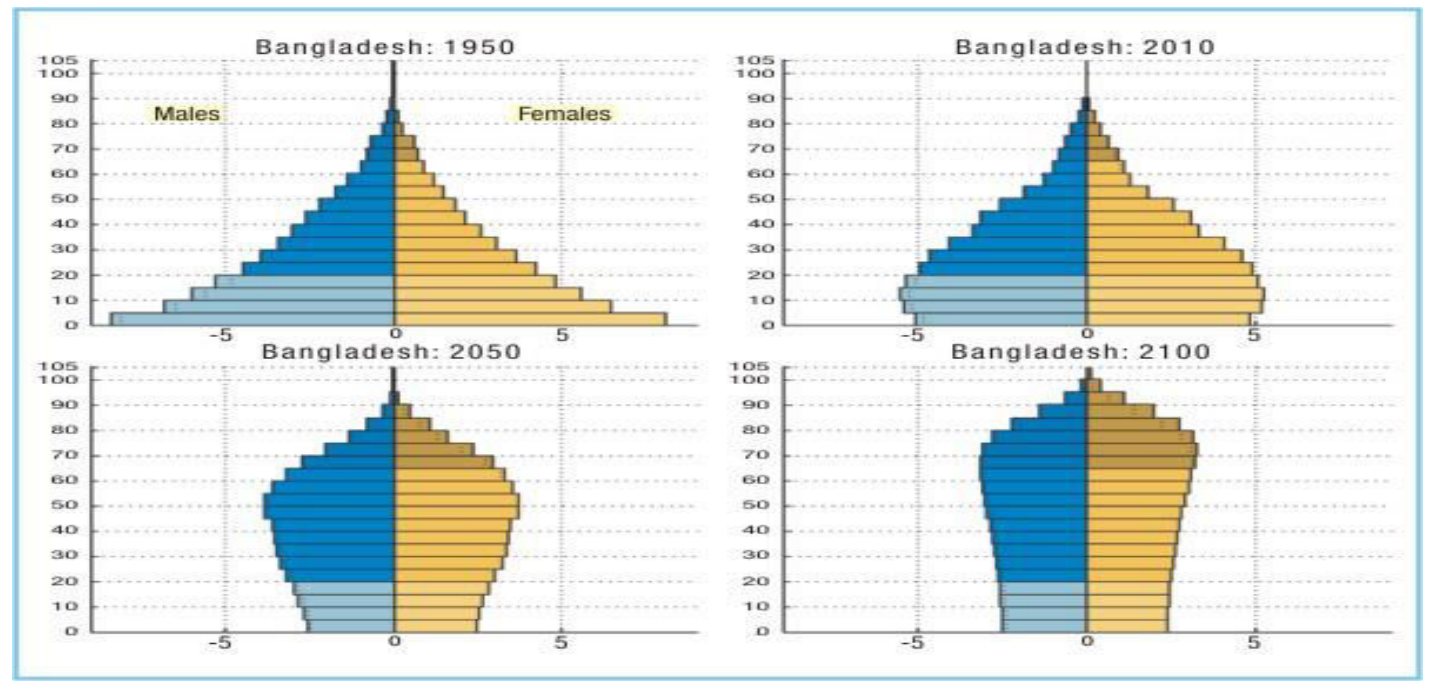

Source: WPP, 2019

Fig 1: Change in Age Structure over Time.

Elderly support in Bangladesh is still reliant on the traditional joint family system. But the times are changing now. Traditional joint and extended families are collapsing, making way for nuclear families. The authority structure is also becoming more egalitarian in rural and urban families (Sarker, 1993). Today's busy lifestyle has left very little scope for looking after older generation of the family on a continuous basis, even if some of them require constant attention for health or some other problems. A degradation of social values and norms also causes elderly to lose their esteemed position in the family and in many cases they are looked upon as burden rather than assets.

Government of Bangladesh started a social security scheme for elderly people in 1998 (Mazumdar, Bangladesh Progress towards MIPAA implementation). In the fiscal year of 1997-1998 fiscal, 14 million USD was allocated to the project which was distributed among 0.40 million elderly people. Each person received 1.2 USD per month. This was increased to 6 USD per month in 2016-17 with a budget of approximately 23 million USD covering almost 3.15 million beneficiaries (Mazumdar, Bangladesh Progress towards MIPAA implementation). For the fiscal year 2018-19 Government has already allotted 28 million USD for elderly support and has targeted to increase the coverage to 4 million (Ministry of Social Welfare). More money has been allocated for 2019-20 (about 31 million) with the objective to add additional 4 million people to previous coverage (Ministry of Social Welfare).

Although there is a social stigma against old home in Bangladesh, nevertheless over the years the number of people in those homes is slowly rising. At first it was an entirely private initiative, but now Government has stepped in and initiated old home program in 2015-16. 06 Old homes were established in 06 Divisions of the Country run by the Department of Social Services under Ministry of Social Welfare.

\section{Ageing indicators}

There are many indicators of ageing. Of those, median age, ageing index and old-age dependency ratio are pertinent to the discussion.

\section{Median age}

This age acts as a watershed, half of the population is younger and half of the population is older than this age (Haupt \& Kane, 2004). From 1950 to 2000, 
median age of Bangladeshi population decline by 2 years, but over the next half century it will increase by 15 years (Rahman et al., 2009).

\section{Index of Ageing}

Expressed as the percentage of people 65 and over to persons under 15 years of age (UN Population Division, 2002). It is growing rapidly and is expected to increase 5.7 times than the current rate by 2050 .

\section{Old-age dependency ratio}

The ratio of persons in dependent age (less than 15 and over 64 years) to those in the economically productive (15-64 years) age group (Haupt \& Kane, 2004). This can be further separated into youth and old age dependency ratio. We are concerned with old age dependency ratio, i.e. ratio of older people to economically productive people (UN Population Division, 2002).

Table 2: Changes in OADR in Bangladesh.

\begin{tabular}{|l|l|}
\hline Year & OADR \\
\hline 1991 & 11.0 \\
\hline 2001 & 11.2 \\
\hline 2010 & 7.0 \\
\hline 2025 & 7.8 \\
\hline 2050 & 16.2 \\
\hline
\end{tabular}

\section{Source:}

BBS, 2003, Population Census 2001, National Report BBS, 2015, Population Monograph, 2015

UN Population Division, 2002

World Bank Data, 2010

\section{Support ratio}

There are two different of support ratios we have to take into account. Potential support ratio, which describes the ration of people in economically productive age group to every elderly person over 64 years, and the parent support ratio which refers to people aged 85 and over to every 100 person within 15-64 year age bracket (UN Population Division, 2002).

Support ratios indicate the burden economically active population has to carry in terms of caring for the economically unproductive population. Increasing support ratios have a potentially detrimental effect on national economy. Even if we have a large section of active population, much of their contributions will have to be spent on taking care of geriatric population.

Table 3: Changes in Support ratio in Bangladesh: From Past to Future.

\begin{tabular}{|l|l|l|l|l|l|}
\hline & $\mathbf{1 9 5 0}$ & $\mathbf{1 9 7 5}$ & $\mathbf{2 0 0 0}$ & $\mathbf{2 0 2 5}$ & $\mathbf{2 0 5 0}$ \\
\hline $\begin{array}{l}\text { Potential } \\
\text { Support } \\
\text { Ratio }\end{array}$ & 16.2 & 14.8 & 18.6 & 12.9 & 6.2 \\
\hline $\begin{array}{l}\text { Parent } \\
\text { Support } \\
\text { Ratio }\end{array}$ & 0.6 & 1.0 & 1.5 & 1.4 & 3.2 \\
\hline
\end{tabular}

Source: UN Population Division, 2002

\section{Critical issues facing elderly population}

\section{Poverty}

Specific information about poverty in the age group 60 and above has not been obtained adequately. It was estimated that about $43 \%$ elderly belong to poor household, this figure might be less than actual since poor people has a lower life expectancy and aged people are likely to be under-represented among the poor (World Bank, 2006). One study showed that about $47 \%$ of elderly did not possess cultivable land, and $5 \%$ did not even possess household land with women in a far worse position than men in both the cases (Kalam \& Khan, 2006).

In earlier times old members of the family were accorded high respect due to their experience and seniority. They were able to live the last stages of their life relatively comfortably. This is not the case now. It has now become very difficult for many to earn enough to support their own families, let alone previous generations. Sometimes children migrate away from home for a better living, leaving parents behind. Sometimes aged people are left in old homes. So if the elderly has no source of income by themselves, they are most likely to suffer from poverty.

Barkat et al., (2006) identified several factors that exacerbate poverty among elderly section of our population, these are: 
- Poor health, hampering ability for productive work.

- Lack of job opportunities for offspring

- Loss of productive land from natural causes.

- Selling of land or other assets for dowry or health costs.

- Natural disasters, e.g. flood, cyclones, drought.

- High interest loans.

\section{Health concerns}

Health issues of the old people have not yet received the required attention, and are increasing at an alarming rate (Uddin et al., 2010). Geriatric wards are common in hospitals of developed countries, which is not the case here. Elderly people usually have multiple health problems, so they need special attention and meeting their health needs take special training to fulfill. Our medical education system does not put much emphasis on it and therefore there are many lackings in this field. Streatfield and Mostofa (2009), in a study of elderly health issues in Bangladesh, found out the followings -

- Arthritis was the most prevalent chronic diseases among aged persons.

- Chronic morbidity was found higher in females, leading to the lack of ability to carry out daily activities.

- Compared to their male counterpart, females were less healthy

Only $56 \%$ of the geriatric population seeks treatment for their health problems, and majority of them (about $55 \%$ ) go to quacks (Kalam \& Khan, 2006). There is only one specialized institute for elderly, Bangladesh Association for the Aged and Institute of Geriatric Medicine (BAAIGM). Government Medical Colleges and private hospitals do not have geriatric departments. Therefore aged people are given treatment with other patients which is not proper considering their special situation.

\section{Living Arrangements}

As has been already described above, family remains the principal support for their aged up until now, although some changes are set into motion. In less developed countries like Bangladesh family appears to UniversePG I www.universepg.com be the primary institution for older people and their well-being is greatly dependent upon their living arrangement (Albert and Cattell 1994). A study by ICDDRB in Matlab in 2008 showed that a greater proportion of elderly people live with their spouse, kin or children. A study found that $79 \%$ households were headed by the elder members (Rajan et al., 2003). However their status is downgraded as soon as they lose their earning power.

\section{Job opportunities for elderly}

A paid job is vital to socio economic well-being of elderly people. It not only reduces his dependence on family members, but also provides him with a sense of satisfaction and authority. In Bangladesh, greater than $70 \%$ of men are paid workers in urban and rural societies and the proportion of elderly in labor force diminishes with age (Kabir et al., 1998). A study involving three districts of Bangladesh found that $63 \%$ elderly were jobless, $15 \%$ were farmers and $14 \%$ continued with their businesses (Taj et al., 2010).

\section{Elderly people and economic activity}

Population ageing is a grave threat to us due to limited resources of our country. Development process brings rapid changes to social institution and behavior which may have adverse implications for elderly care (Kabir, 1999).

As the population ages, labor force will gradually shrink, a problem which some developed countries are already facing. This may lead to sluggish economic activity. Also, to meet special needs of elderly people will require huge amount of funds to be diverted from other sector. The social safety net will keep growing resulting in a great stress on national economy. Our GDP, GNP and other indicators will be affected.

The overall effect will undoubtedly be an economic slowing and a period of great spending by the government to care for the aged. How much it will actually trouble us is will depend on what are we going to do about it. We can surely incorporate elderly people in development planning and make use of their truckload of experience, thus treating them as assets rather than burden. 


\section{National policy on ageing}

In line with United Nations (2007) Madrid International Plan of Action on Ageing (MIPAA), the Ministry of Social Welfare finalized the National Policy on Ageing (Sultana, 2011). The objectives of this policy are:

- Reinforce the dignity of the elderly section of the population

- Recognize the problems of the elderly people and address those.

- Bring positive changes in the attitude of the mass people towards the elderly people.

- Initiate new programmes to address the socioeconomic needs of the elderly people

- Implement special measures to support elderly peoples in emergencies, e.g. natural calamities, cyclone, earthquake etc.

- Ensure proper health care, social security and generate opportunities for employment and rehabilitation.

Strategies to implement included (Hasan, 2007):

- Ministry of Social Welfare has been entrusted to implement the above policy and already chalked out an Inter-ministerial action plan.

- Integration of public, private and International efforts to ensure implementation of various programmes.

- Short term, midterm and long term programmes has been chalked out.

- Special budget allocation has been made for different programmes.

- Data is continuously collected for the welfare of elderly people.

- Required legal rules and regulations have been devised.

- National awareness building campaign are initiated.

\section{CHALLENGES AHEAD}

We must think of the challenges we have to face so that we will be not caught unprepared. The challenges are many, but there are a few we must address:

- To meet the special and varied health problems of elderly a total overhaul of our health system is necessary. This will require a lot of time and money.

- In future we have to deal with a considerable number of elderly people without any family support. The state has to take direct responsibility, which means a new avenue of spending.

- Expansion of social security net requires extensive amount of resources.

- We need to train them and acquaint them with modern technology so that they can actively contribute in the overall development.

- Implementation of national policy on ageing needs commitment from highest political level.

- Most important of all, we have to identify ageing of the population as a real problem from the highest level of the government.

\section{What can be done}

- Reinforce and strengthen social value system to ensure continued family support for elderly b a massive public campaign

- Bring the population ageing issue on the forefront in policy making, decision taking and development effort

- People should be made aware of adverse consequences we are going to face due to population ageing.

- Treat elderly people as assets and integrate them with overall development planning.

- Establish old homes both by government and private sector and take steps for proper management of these homes.

\section{CONCLUSION:}

Bangladeshi society is experiencing a demographic transition. If the demographic dividend is leveraged appropriately then rapid economic and social development is possible. Proper planning and timely execution can really propel the country into world's elite. But the looming danger of population aging must also be kept in mind. The increasing size of elderly population and their related socioeconomic and gerontological aspects are slowly emerging as a population discourse in our country (Khan, 2009). So 
Bangladesh should brace for their impact, both on our population and development. How this impact will be absorbed will depend entirely how the current window of opportunity with a relatively young population is going to be utilized.

\section{ACKNOWLEDGEMENT:}

Many thanks Dr. A.K.M. Nurun Nabi, Professor, Department of Population Sciences, University of Dhaka and Dr. Mohammad Mainul Islam, Professor, Department of Population Sciences, University of Dhaka to conduct successful study.

\section{CONFLICT OF INTEREST:}

There is no conflict of interest of the research study.

\section{REFERENCES:}

1) Albert, S. M. \& Cattell, M. G. (1994). "Family Relationships of the Elderly: Living Arrangements", Old Age in Global Perspective: Cross-Cultural and Cross-National Views, G.K. Hall \& Co. New York, pp. 85107.

2) Bangladesh Bureau of Statistics (1980), Statistical Pocketbook of Bangladesh, 1979, Ministry of Planning, Government of the People's Republic of Bangladesh, Dhaka.

3) Bangladesh Bureau of Statistics (2007), Population Census 2001, National Series, Volume 1, Analytical Report, Ministry of Planning, Government of the People's Republic of Bangladesh, Dhaka.

4) Bangladesh Bureau of Statistics (2007), Report on Sample Vital Registration System, 2005-2006, Ministry of Planning, Government of the People's Republic of Bangladesh, Dhaka.

5) Bangladesh Bureau of Statistics (2007), Population Census 2011: Preliminary Report, Ministry of Planning, Government of the People's Republic of Bangladesh, Dhaka.

6) Bangladesh Bureau of Statistics (2009), Report on Sample Vital Registration System, 2008, Ministry of Planning, Government of the People's Republic of Bangladesh, Dhaka.

UniversePG I www.universepg.com
7) Bangladesh Bureau of Statistics (2009), Report on Sample Vital Registration System, 2008, Ministry of Planning, Government of People's Republic of Bangladesh, Dhaka.

8) Bangladesh Bureau of Statistics (2015), 'Population Distribution and Internal Migration in Bangladesh', Population Monograph, Vol 6.

9) Barkat, A. et al., (2003), Chronic Poverty among Older People in Bangladesh. http://www.hdrcbd.com/pcs_pdf/5\%20Poverty 104.\%20Chronic\%20Poverty\%20among\%200 lder\%20People\%20in\%20Bangladesh.pdf

10) Department of Social Services, the Government of Bangladesh (2011), Old Age Allowances.

http://www.dss.gov.bd/index.php?option=com _content $\&$ view $=$ article\&id=59:old-age-allo wances\&catid=39: social-cash-

11) Habib MA, Akter S, Rahman A, Sikder J, Khatun F, Mizan MFR, Ashrafudoulla M, and Hannan MA. (2019). Evaluation of Neuropharmacological Activities of Methanolic Extract of Bacopa monnieri L. in Mice Model. European J. of Medical and Health Sciences, 1(6), 41-49.

https://doi.org/10.34104/ejmhs.01941049

12) Hasan, M. (2007), 'Country report on Bangladesh', Paper presented at the Highlevel Meeting on the Regional Review of the Madrid International Plan of Action on Ageing (MIPAA) at China (October 9-11).

13) Haupt, A. \& Kane, T. (2004), Population Handbook, $5^{\text {th }}$ edition, Population Reference Bureau, pp. Washington DC, pp. 6-7.

14) Islam, M. (2011), 'The People Problem', Forum, Vol. 5, no. 7.

15) Jesmin, Syeda S. \& Ingman, Stanley R. (2011), 'Social Support for Older Adults in Bangladesh', The Journal of Aging in Emerging Economies, pp. 69-79.

16) Kabir, H., (1998). 'Local level policy development to deal with the consequences of population ageing in Bangladesh', United Nations, pp. 33.

17) Kabir, M. (1999), Demographic and Economic Consequences of Aging in 
Bangladesh, Centre for Policy Dialogue, Dhaka, pp.1-10.

18) Kabir, Z.N., Szebehely M., Tishelman C. (2002), Support in old age in the changing society of Bangladesh', Ageing and Society, 22, 615-636.

19) Kalam, Shafiqul I. M. \& Khan, Hafiz T. A. (2006), 'Mobidities among Older People In Bangladesh: Evidence From An Ageing Survey', BRAC University Journal, 3(2), 7583.

20) Khan, M. H. (2007), 'The Emerging Ageing Situation in Bangladesh', Bold, 17 (2), 12-17.

21) Lee, R. 2011, 'The Outlook for Population Growth', Population Bulletin, 66 (2), 570.

22) Mabud, Mohammad, A. (2008), Bangladesh Population: Prospects and Problems. http://www.google.com/url?sa=t\&rct=j\&q= aged+bangladesh+population+statistics\&sour ce $=$ web \&cd $=6 \& v e d=0$ CFcQFjAF\&url $=$ http $\%$ 3A\%2F\%2Fwww.northsouth.edu\%2Fphp $\% 2 \mathrm{~F}$ faculty\%2FBangladesh_population.doc\&ei=Y VuVT6DNEYKJrAeu1uWCBQ\&usg=AFQjC NEq9SVECLCPyiTy3Y_O6DSjQoJQpA21/4 $\underline{12}$

23) Mazumdar, M. K., Bangladesh Progress towards MIPAA implementation.

https://www.unescap.org/sites/default/files/2.\% 20MIPAA\%20Focal\%20Point $\% 20$ Presentation1 \%20\%28Bangladesh\%29.pdf

24) Ministry of Social Welfare, Government of Bangladesh.

https://msw.portal.gov.bd/sites/default/files/ files/msw.portal.gov.bd/page/15759e9f_5651_ 4bcd b94d 9a0f3c165ce0/Final\%20Safety\%2 0net\%20_Bangla\%202019-20.pdf

25) Mostofa, G. \& Streatfield, P. K. (2002), Health Issues of an Ageing Elderly Population, http://www.icddrb.org/mediacentre/fact-sh eets/cat_view/52-publications/ 10042-icddrb-periodicals/10073-scientificconferences/10 339-10th-ascon-2002/13825oral-session-17-household-food-expenditureand-food-consumption

26) Rabbi, A. M. F \& Stefano M. (2018), 'Mortality and life expectancy forecast for (comparatively) high mortality countries', Genus. 74(18), 1-10.

27) Rahman, K. M. M, Tareque, M. I \& Rahman, M. M. (2011), The Effects of Bangladesh Land Tenure System on Rural Elderly People of Naogaon District, Sacha Journal of Policy and Strategic Studies, 1(1), 46-47.

28) Rahman, Mustafizur K. M., Ibn Mohsin, M. \& Tareque, I. (2009), 'Trends of Population Ageing from 1950-2050: A Comparative Study between Bangladesh and World', Pakistan J. of Social Sciences, 6(1), 6-9.

29) Rajan, S. I., Perera, M. \& Begum, S. (2003), Economics of Pensions and Social Security in South Asia: Special Focus on India, Srilanka and Bangladesh.

http://www.saneinetwork.net/Files/02_04.pdf

30) Rahman MA, Ahmad T, Mahmud S, Hossain MR, Uddin ME, and Ahmed R. (2019) Isolation, Identification and Antibiotic Sensitivity Pattern of Salmonella spp from Locally Isolated Egg Samples. Am. J. Pure Appl. Sci., 1(1), 1-11. https://doi.org/10.34104/ajpab.019.019111

31) Sarker, P. C. (1993), 'Decline of traditional family system and reproductive behavioue in rural Bangladesh', Indian Jouranal of Social Science, 6(1), 65-75.

32) Sharif IH, Mosaib MG, Tamanna N, Haque MA, and Uddin ME. (2019) Assessment and biomonitoring of the effect of rapeseeds oil on wister rat organs. Am. J. Pure Appl. Sci., 1(4), 20-29.

https://doi.org/10.34104/ajpab.019.0192029

33) Statista (2019), Bangladesh: Average age of the population from 1950 to 2050; https://www.statista.com/statistics/438196/ave rage-age-of-the-population-in-bangladesh/

34) Streatfield, P. K. \& Karar, Z. A. (2008), 'Population Challenges for Bangladesh in the Coming Decades', Journal of Health Population Nutrition, 26 (3), 265-266.

35) Sultana, T. (2011), 'Expectations, Realities and Coping Strategies of Elderly Women in a Village of Bangladesh', Bangladesh Development Research Working Paper Series, 13, 4-8. 
36) Taj Uddin, M., Nazrul, Md. I., Johurul Md. A. \& Baher, G. U., (2010), 'Socio-Eonomic Status of Elderly of Bangladesh: A Statistical Analysis. J. of Applied Sciences, 10, 30603067.

37) Uddin, M. J. \& Karim, M. R. (2016), 'Harnessing the Demographic Dividend: Opportunities and Challenges for Bangladesh', IOSR Journal of Humanities and Social Science, 21(8), 8-13.

38) United Nations, World Population Prospects, the 2008 Revision.

https://www.un.org/en/development/desa/pop ulation/publications/trends/populationprospects.asp

39) United Nations Population Division, World Population Prospects (2019).

https://population.un.org/wpp/Graphs/Demogr aphic Profiles/Pyramid/50

40) United Nations Population Fund (2009), Family Support Networks and Population Ageing. https://www.unfpa.org/sites/default/files/ pubpdf/family_support_networks2009.pdf

41) United Nations Population Division (2002), World Population Ageing 1950-2050, pp. 6-27 \& 41-42.
42) U.S. Census Bureau, International Data Base. http://www.census.gov/population/internation al/data/idb/informationGateway.php

43) World Bank (2011), Age Dependency Ratio (\% of Working Age Population).

http://data.worldbank.org/indicator/SP.POP.D PND.OL

44) World Bank (2019), Age Dependency Ratio: Older Dependents to Working-Age Population for Bangladesh [SPPOPDPNDOLBGD], retrieved from FRED, Federal Reserve Bank of St. Louis.

https://fred.stlouisfed.org/series/SPPOPDPND OLBGD

45) World Bank (2019), Life expectancy at birth, total (years).

https://data.worldbank.org/indicator/SP. DYN. LE00.IN

46) World Health Organization, (2018), Health SDG Profile: Bangladesh.

http://www.searo.who.int/entity/health situation_trends/cp_ban.pdf

47) World Population Review (2019), Bangladesh Population 2019.

http://worldpopulationreview.com/countries/b angladesh-population/

Citation: Ahmed I. (2019). The impact of ageing on population structure and development process of different levels of Bangladesh. Eur. J. Med. Health Sci., 1(6), 50-58. https://doi.org/10.34104/ejmhs.01950058 (C) (9) 